\title{
Inter-stage right ventricular remodeling in hypoplastic left heart syndrome
}

\author{
Aaron Bell ${ }^{1}$, Hannah R Bellsham-Revell ${ }^{2 *}$, Philipp Beerbaum², Reza Razavi ${ }^{2}$, Gerald Greil ${ }^{2}$ \\ From 2011 SCMR/Euro CMR Joint Scientific Sessions \\ Nice, France. 3-6 February 2011
}

\section{Background}

Magnetic resonance imaging (MRI) can be used as a means of pre-operative evaluation of the cardiac anatomy and function in patients with hypoplastic left heart syndrome (HLHS) prior to superior and total cavo-pulmonary connection (TCPC). Serial MRI evaluation prior to each cavo-pulmonary palliation allows us to demonstrate the remodelling of the right ventricle.

\section{Methods}

A retrospective analysis of the serial MRI scans of all patients with HLHS who had undergone palliation through to completion of Fontan was undertaken. Re-analysis was undertaken by two members of the research team who had previously shown good intrauser variability. Ethical and institutional approval was obtained. All scans had been performed with general anaesthesia on a Philips 1.5 Tesla Intera MRI scanner.

\section{Results}

51 patients had undergone completion of Fontan and had MRI scans performed prior to each cavo-pulmon- ary connection available for analysis. Median (range) age in years at the first MRI, superior cavopulmonary connection, pre-TCPC MRI and TCPC was 0.44 (0.12-1.02), 0.57 (0.13-1.37), 2.80 (1.80-5.52), 3.26 (2.28-6.76) respectively. Right ventricular (RV) volumes indexed to body surface area are demonstrated in table 1 . There was a marked reduction in indexed RV end diastolic volume (iEDV), indexed RV end systolic volume (iESV). Indexed stroke volume (iSV) remained constant, but indexed cardiac output (iCO) fell, likely due to the decrease in heart rate (HR) between the two scans. There was an increase in global ejection fraction (EF).

\section{Conclusions}

The right ventricle undergoes significant remodelling between palliative stages. Reduction in the volume loading by replacing a shunt dependent circulation with a cavo-pulmonary connection significantly alters right ventricular volumes and improves function.

Table 1

\begin{tabular}{|c|c|c|c|c|c|c|}
\hline & $\begin{array}{l}\text { Heart Rate } \\
\text { median (range) }\end{array}$ & $\begin{array}{l}\text { iEDV (ml/m2) } \\
\text { median (range) }\end{array}$ & iESV median (range) & iSV median (range) & $\begin{array}{l}\text { iCO median } \\
\text { (range) }\end{array}$ & $\begin{array}{l}\text { EF median } \\
\text { (range) }\end{array}$ \\
\hline $\begin{array}{l}\text { MRI prior to superior } \\
\text { cavo-pulmonary } \\
\text { connection }\end{array}$ & $115(83-150)$ & 91.90 (48.67-213.63) & $45.13(15.31-126.5)$ & 47.33 (19.91-105.77) & $5.12(2.49-13.36)$ & $51.4(28.4-72.4)$ \\
\hline $\begin{array}{l}\text { MRI prior to total } \\
\text { cavo-pulmonary } \\
\text { connection }\end{array}$ & $85(57-133)$ & 84.45 (46.42-152.10) & $36.12(14.38-64.97)$ & $48.02(32.02-98.73)$ & $4.15(3.01-8.20)$ & $59(43.2-76.2)$ \\
\hline
\end{tabular}

${ }^{2}$ King's College London, London, UK

Full list of author information is available at the end of the article

(c) 2011 Bell et al; licensee BioMed Central Ltd. This is an open access article distributed under the terms of the Creative Commons 


\title{
Author details
}

'Guy's and St Thomas' Foundation NHS Trust, London, UK. 'King's College

London, London, UK.

Published: 2 February 2011

\author{
doi:10.1186/1532-429X-13-S1-P205 \\ Cite this article as: Bell et al:: Inter-stage right ventricular remodeling in \\ hypoplastic left heart syndrome. Journal of Cardiovascular Magnetic \\ Resonance 2011 13(Suppl 1):P205.
}

Submit your next manuscript to BioMed Central and take full advantage of:

- Convenient online submission

- Thorough peer review

- No space constraints or color figure charges

- Immediate publication on acceptance

- Inclusion in PubMed, CAS, Scopus and Google Scholar

- Research which is freely available for redistribution

Submit your manuscript at www.biomedcentral.com/submit 